$$
\prod_{\substack{\text { UCRL-JC-120641 } \\ \text { PREPRINT }}}
$$

\title{
A Computational Method for Comparing the Behavior and Possible Failure of Prosthetic Implants
}

\author{
C. Nielsen \\ K. Hollerbach \\ K. Underhill \\ S. Perfect \\ This paper was prepared for submittal to the \\ EMBS 95 Conference \\ Montreal, Canada \\ September 20-23, 1995
}

\section{May 1995}

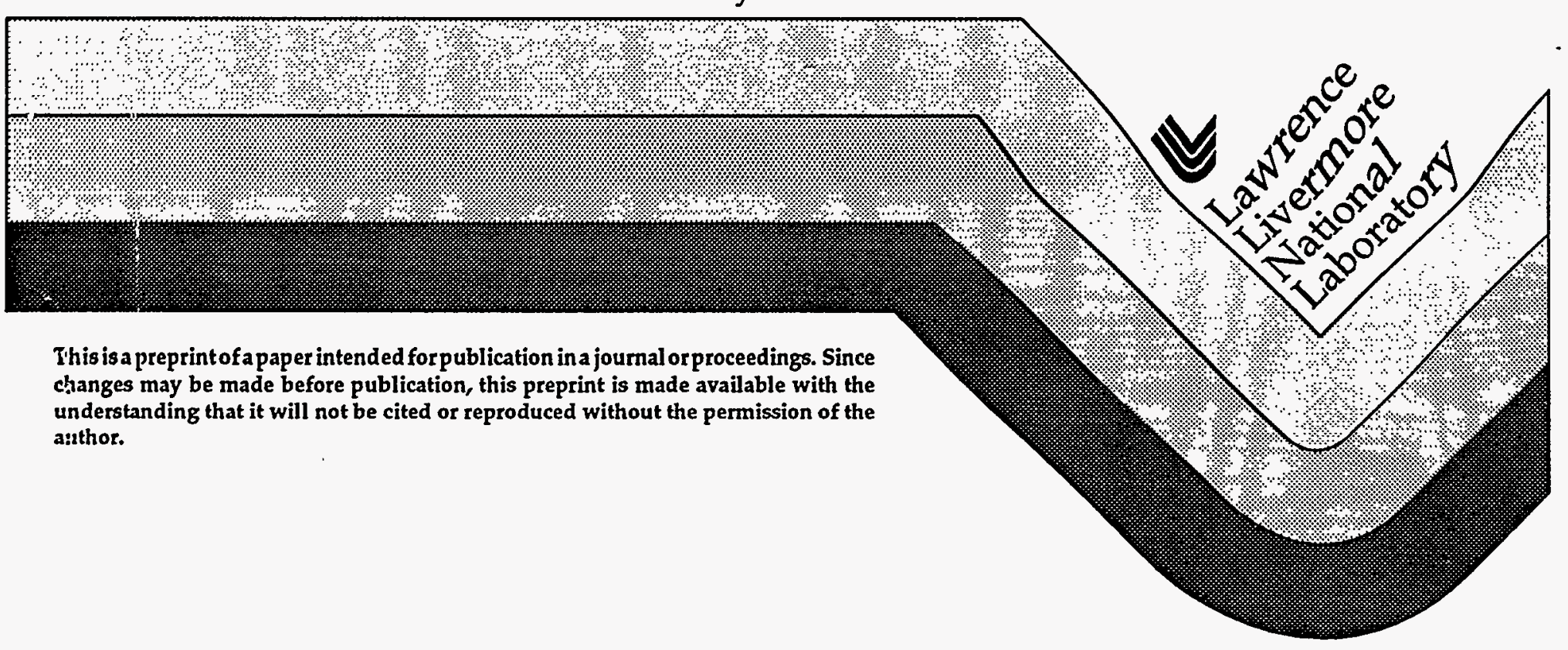




\section{DISCLAIMER}

This report was prepared as an account of work sponsored by an agency of the United States Government. Neither the United States Government nor any agency thereof, nor any of their employees, make any warranty, express or implied, or assumes any legal liability or responsibility for the accuracy, completeness, or usefulness of any information, apparatus, product, or process disclosed, or represents that its use would not infringe privately owned rights. Reference herein to any specific commercial product, process, or service by trade name, trademark, manufacturer, or otherwise does not necessarily constitute or imply its endorsement, recommendation, or favoring by the United States Government or any agency thereof. The views and opinions of authors expressed herein do not necessarily state or reflect those of the United States Government or any agency thereof. 


\section{DISCLAIMER}

Portions of this document may be illegible in electronic image products. Images are produced from the best available original document. 


\title{
A COMPUTATIONAL METHOD FOR COMPARING THE BEHAVIOR AND POSSIBLE FAILURE OF PROSTHETIC IMPLANTS
}

\author{
C. Nielsen ${ }^{1}$, K. Hollerbach ${ }^{1}$, S. Perfect ${ }^{2}$, K. Underhill ${ }^{1}$ \\ ${ }^{1}$ Institute for Scientific Computing Research, L-416 \\ ${ }^{2}$ New Technologies Engineering Division, L-126 \\ Lawrence Livermore National Laboratory, P.O. Box 808, Livermore, CA 94550
}

\begin{abstract}
Prosthetic joint implants currently in use exhibit high failure rates. Realistic computer modeling of prosthetic implants provides an opportunity for orthopedic biomechanics researchers and physicians to understand possible in vivo failure modes, without having to resort to lengthy and costly clinical trials. The research presented here is part of a larger effort to develop realistic models of implanted joint prostheses. The example used here is the thumb carpo-metacarpal (cmc) joint. The work, however, can be applied to any other human joints for which prosthetic implants have been designed. Preliminary results of prosthetic joint loading, without surrounding human tissue (i.e., simulating conditions under which the prosthetic joint has not yet been implanted into the human joint), are presented, based on a thrce-dimensional, nonlinear finite element analysis of three different joint implant designs.
\end{abstract}

\section{Introduction}

Eight percent of the U.S. population is affected by CMC osteoarthritis. Relief of pain in osteoarthritis depends on eliminating the incongruous articulating surfaces where high and non-normal forces are generated. The ratios of joint forces to the applied force have becn calculated by Giurintano et al. (1994) to be about 18 times the applied load in a power pinch. The thumb power in pinch and grip measured by Crosby et al. (1994) is $27 \mathrm{lb}$. This means that the normal CMC joint routinely sees forces in exccss of $500 \mathrm{lbs}$. A replaccment joint must be able to handle these forces repetitively without dislocating, wcaring out, or cutting out of the bones.

Examination of ultra-high molecular weight polycthylene (simply called "polyethylene" hercafter) total joint prosthetic components in pre-implant tests and in tests following revision or removal surgery has shown that polycthylene wear is a serious problem in joint replacements (Wright et al. 1986). Polycthylene is frequenty used to provide the articulating surfaces of joint implants and is thus subject to high degrees of contact stress in normal joint articulation and loading. A common failure mode in polyethylene components is sub-surface cracking in the presence of high stresses (Wright et al. 1986, DeHeer 1992), such as those found in normal thumb activity.

Our objective has been to test several thumb CMC joint implant designs by determining contact stresses under a well-defined set of boundary conditions: The implant was modeled alone, and uniaxial loading was applied to the articulating components.

\section{Methods}

The 3D joint implant models were based upon 3D iges surface definitions of three commonly used implant designs. The surfaces were read into TrueGrid software (XYZ Scientific Applications, Inc., Livermore, CA), and a volumetric mesh was created for each component of each implant design. Design goals for implant design A include long term pain relief and restoration of thumb function, including strength and dexterity, following injury and disease. The implant consists of (1) a polyethylene-titanium component, where the polyethylene provides the articulating surface and is reinforced with a metal saddle to prevent deformation, minimizing fatigue; the titanium stem is inserted into the metacarpal canal; and (2) a trapezial cobalt-chrome implant that is saddle shaped to increase metaphyseal bone surface contact area with the prosthesis and thereby decrease the forces per unit area of bone. Small pegs on the implant provide initial stability, but long term stability of the implant is dependent on wide metaphyseal bone contact. The articulating surfaces are the surfaces of revolution for the $\mathrm{CMC}$ joint axes. The surfaces are highly congruent, to reduce component wear. Joint stability is provided by the deeply saddle-shaped surfaces. Design $B$ was a ball and socket joint, a scmi-constrained implant, with the socket residing on the trapezial side and lined with a polyethylene component, and the ball making up the articular surface of the metacarpal side, composed either titanium or cobaltchrome. Design rationale for this implant design includes the desire to make a geometrically simple joint connecting the two bones in such a manner that dislocation is resisted under axial loading and moderately resisted under anteriorpostcrior and medial-lateral loading. The implant, while uscd to replace a 2 degree of freedom biomechanical joint, is a 3 degree of freedom mechanism. Design $C$ is a onepiece silicone replacement designed to be implanted into metacarpal bone, with excision of the trapezium. This style of implant has been shown to be associated with destructive changes in the surrounding bone and related synovitis in a large fraction of clinical cases tested (Hofammann, 1987) and is usually recommended only in the elderly and only in hands of which little high-load activity is required.

NIKE 3D is a nonlinear, implicit, three-dimensional finite clement code developed at the Lawrence Livermore National Laboratory for the purposes of studying dynamic, finite deformations. Spatial discretization is achieved in 
this model using 8-node solid (hexahedral) elements. Metal pieces were modeled as rigid bodies; the preliminary material model used for the polyethylene pieces was an isotropic, elastic model with varying clastic moduli tested.

The results described here are based on two analyses with a well defined set of boundary conditions. In the first simulation, we fix the trapezial component in all six degrees of freedom, and we uniaxially load the mctacarpal component to force contact between the two parts. The resulting contact forces on the articular surfaces of the metacarpal and trapezial components are calculated and some measure of congruency between the two components is established. Prior to loading, the parts are perfectly. aligned with one another, so that the uniaxial normal loading force does not act to bring the componenis into proper alignment. This simulation describes the erents that would occur inside a uniaxially loaded joint, assuming it had been implanted perfeculy. In reality, joints are implanted with some degree of mis-alignment. In the second simulation, we begin with the metacamal implamt mis-aligned slightly with respect to the trapezial implam. The uniaxial loading, however, is the same. Again. contact stresses and degrec of congruency are csublished.

\section{Results \& Discussion}

All three implant designs were meshed and analy\%cd (Fig. $1 \mathrm{a}, \mathrm{b}, \mathrm{c}$ ). Suge one of the analysis represented a proof of concept demonstration that the finite clement code could be applied successfully to analy'ze large defonmation dynamies involving articulating components. Successful application of the codes was demonstrated in all threc cases.

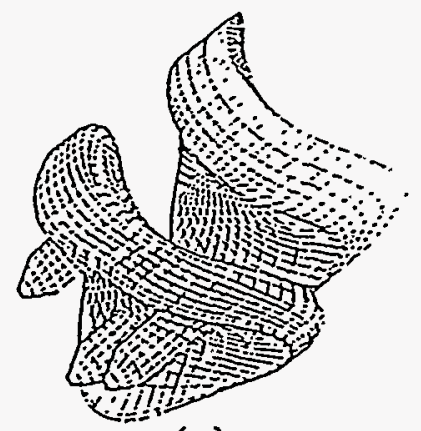

(a)

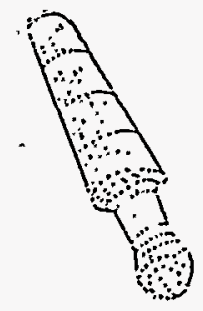

(b)

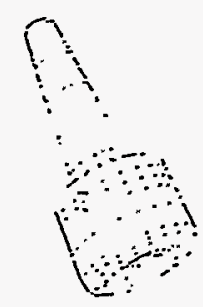

(c)
Figure 1: (a) implant design $A$. (b) impl:mu dexign B a h:ll

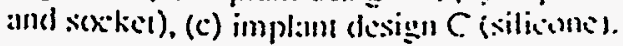

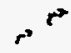

Stage two involved uni-axial loading of the joints and calculations of congruency measures of the articulating implant components and the resulting contact stresses. Concentrated regions of high stress are thought to represent danger zones for joint failure due to the polycthylene surface failure mode. As expected, low measurcs of congruency tended to increase areas of contact stress. With loading in the physiological range (i.e., up to $500 \mathrm{lbs}$ ), some areas of suress that exceeded the limits of polycthylene were found.

The ability to model large deformation bchavior of prosthetic joint implants is significant, because it sets the stage for realistic modeling analysis of the prostheses when implanted into the human joint. The work complcted thus far has involved modeling of uniaxial loading of the joint implants alone. In addition, we have modeled contact behavior simulating imperfect surgical implantation, with initial conditions set to model implant components offset from their idea position and orientation with respect to one another. We are currently working to combine the implant modcls with our existing models of the normal. joint biomechanics, without an implant. Using the resulting implant plus bone model will be used to describe the in vivo behavior of the implant. With such a modicl, we will then perform out analysis of all threc failure modes. polycthylene surface failure, failure to reproduce normal joint kincmatics (c.g.. by producing a joint with a different number of degrees of frecdom or by producing incorrect offsets for the joint axcs of robation). and failure at the bone-implant interface. This work, in the larger context of being able to model the prosthetic implant-human tissuc sy'sicm and the inicractions of the rarious inatcrials, provides a significantly improved mcthed for craluation of prosithet: joint implant designs. The methods and codes used can be applicd to any odicr join for which surface descriptions of the implants and human tissucs can be obtuined.

\section{Acknowledgments}

This rescarch has been supporled in part by the Lawrence Livermore National Laboralory's LDRD program, under Eram 93-ERI-(153. and we the U.S. Department of Encrey's SERS program.

\section{References}

III Crosby et al. (1994) Hand strengh: normaltive valucs. J. Hand Surgery. 19(-1):665-670.

(2) DeHecr (1992) Siresses in polycthylez: thial

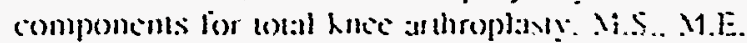
Dept., Purduc lniversiry.

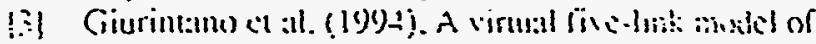
llke thumb (in press).

:-1 Niright 7M, and Barlel. DL (19Sioj The problem of surfice damage in polverhylene loisi knee componints. Clinical Orihopuedics and Related Resiarch. 205:67-74.

I5) Holammann, Forlic. Co3yon, M. 1987) Arubroplasty of the hasal joint of the thumb using a silicone prosihesis: Long-term follow-up. I Bone

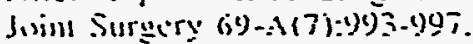

This work was performed under the auspices of the U.S. Dept. of Energy at LLNL under Contract No.W-7405-Eng-48. 